\title{
THE EVOLUTION OF CENTRAL SECURITIES DEPOSITARIES IN EUROPE: STABLE FUNCTIONS IN A CHANGING ENVIRONMENT
}

\author{
Gisèle CHANEL-REYNAUD \\ Dominique CHABERT
}

\begin{abstract}
1 Settlement-delivery (S\&D) operations of CSDs or ICSDs (1) are the second last stage of the securities treatment procedure, the last stage being the delivery of securities into the accounts of the final holders by their account managers/custodians (2). As for national transfers (3), the organisation is fairly simple since regional depositors are directly connected to the central securities depositary which fulfils two overriding functions on their behalf:

- ensuring the final custody of securities and testifying to their authenticity ;

- ensuring the circulation of securities within the market through one or several S\&D systems (4).
\end{abstract}

2 At national level, both these functions are most of the time performed safely, rapidly and at low cost, whereas cross-border operations entail much higher costs (5) and longer time lags. There are actually 33 different S\&D systems in the European 25-country community (6). Other actors play a role in this already sophisticated structure, such as regional and global custodians, and ICSDs which act as depositaries for international securities. This "balkanization" is one of the obstacles to the implementation of financial integration, as pointed out in the two Giovannini reports (7).

3 As a matter of fact, the unification of the financial market is being attempted by fostering competition between the actors, whereas the creation of the single currency implied a "federal" approach by setting up a single organisation to ensure a unified settlement system. This option has led a great many economists to liken S\&D to the transport of goods and sources of energy (Knieps, 2004 ; Van Cayseele, 2005 ; Schmiedel, Schönenberger, 2005), and to advocate the free circulation of securities, while analysing the "natural monopoly" situation of the settlement systems. This situation, they say, is similar to that of the French Railways. There results an attempt at clearly separating the implementation and management of the networks (which might be seen as subject to the logic of natural monopoly) from the users of these networks (who depend on competition). We are in presence of an organisational and technological approach that places particular emphasis on the industrial character of finance. In this approach, financial intermediation is addressed through "transaction costs" rather than risk management, even if risk management is more consistent with the European functional approach.

4 Although we consider this approach interesting, we will here endeavour to adopt another standpoint, focusing on the peculiar nature of financial commodities, and highlighting their kinship with money. We will resort to functional analysis to study the evolution of the different institutions, and compare how money and securities are respectively dealt with. We will eventually infer the changes in the central depositary function that are desirable. 
5 Until the 1980s, the distinction between the monetary and the financial, between currency and securities, was no big issue whatsoever. The two types of instruments were clearly distinguished both theoretically (duality theory, primary and secondary dichotomies) and empirically (completely different circulation networks, no return on currency, distinct maturities, perfect liquidity of currency vs. little liquid securities, high transaction costs for securities against nearly zero cost for currency, significant capital risk for securities, but not for currency). Financial reforms and above all technological progress over the past 30 years have made the distinction more and more difficult to pinpoint (8). It is one of the reasons why the central bank has given up its quantitative policy, and intervenes increasingly to ensure financial stability. In some markets (money markets), securities are perfect substitutes for currencies, and their $\mathrm{S} \& D$ is almost instant (with RGV in particular).

6 In the banking sector, the debts of banks now bear interest, even for individuals, their circulation generates transaction costs, and they can no longer be distinguished from the other debts to issuers, but for exchange at par with central bank currency. Here lies the main divide between securities and money, and here also lies the justification of a central bank for currency, and of a proven free banking system for securities. However, in the eyes of a custodian, this residual difference does not appear to justify such a divergence in the treatment of securities and money, if an increasingly effective substitution is believed to entail the same systemic risks.

\section{THE FUNCTION OF CENTRAL CUSTODIAN WITHIN A NATIONAL DOMESTIC AREA: A CRUCIAL FUNCTION}

7 The function of a custodian has evolved over time. More precisely, the importance of its two components has changed, with the progressive predominance of the circulation of securities over the function that uses trust as a tool.

\section{The stock-related function: trust as a tool}

8 From a functional standpoint, using trust as a tool has provided a basis to the very existence of depositaries. The founding myths of our civilisation show that deposits and depositaries are recurrent metaphors, and that using trust as a tool has been an integral part of the management function of deposits. Punishment (9), whether by Man or the Divinity, has always been a guarantee in case of breach. Trust alone justifies the attitude of the depositor, who ventures to allow his asset out of his sphere of influence - Parliamentary Report (1816). The function of using trust as a tool has been successively exercised by the Divinity, priests (temples), politicians (nationalisation of central banks, banks, central custodians) and, more and more, by independent (ECB), commercial or mutual (CSDs, ICSDs) bodies.

9 However, repayment and the power of a depositary may vary depending on the asset being repaid its original amount, or if fungible, being repaid in the form of an equivalent repayment. This is what lies at the core of the difference between the treatment of securities and money. 
10 In the monetary sphere, deposits are fungible, a bank that issues commercial debts accepted as currency cannot only be considered a custodian, but also a debtor towards depositors with creditor status. In this sense, a bank can use the currency, but it has to repay an amount equal to the amount deposited, plus, possibly, interest. This situation has several consequences:

"Intermediary currency custodians" (i.e. the banks that keep accounts) testify to ownership.

- Banks issue debts that are used for transactions: commercial bank currency. So far in France, they have been the only bodies authorised to manage the circulation of currency. This situation is likely to change with the anticipated implementation of "payment institution" status, distinct from bank status. What we witness here is a situation of competition between the users of settlement procedures, as in the industrial sector.

- Banks can "make the money paid into accounts by their clients work". They are not obliged to separate the amounts credited.

- Depositors, for this reason, are faced with "information asymmetry" (10). Trust is therefore particularly important as far as money is concerned. In the banking sector, trust has become a reality through regulation, nationalisation, size, the diversification of balance sheets, or, more recently, effective risk management allowing to share and diversify the risks banks have to face.

11 Moreover:

- depositors enjoy a guarantee against the declining value of monetary debts of the bank through their exchange at the money with the currency issued by the central bank, within the same payment system (11);

- depositors enjoy a guarantee against defaulting banks thanks to reserve funds ;

- banks are subject to stringent regulation.

The "central custodian" (ie. the central bank) matches stock to demand, and certifies the value of the currency

- As a bank can lend the funds it manages on behalf of its depositors, it is not compelled to re-deposit all these funds with the central bank. Only a very small part is deposited as reserve requirements.

- The role of a central bank is less stocking money than making sure that the amount of currency brought into circulation by the different actors corresponds to the needs of the economy. This justifies its leading role in the conduct of monetary policy, and in providing banks with liquidities (lender of last resort).

- The value of a currency against other currencies is guaranteed by the rigour of a central bank in its management of the money stock.

- A central bank has to authenticate the currency. Though this role looks more technical, it guarantees the real existence of a currency, so as to combat forgery.

12 The function of financial assets depositary 
Financial assets are not so fungible, since the holder, at any moment, stays the owner of a well identified security (eg. thanks to its ISIN); hence a needed separation between the securities held by a custodian on his own behalf, and those held on a client's.

\section{Intermediary custodians testify to ownership}

An intermediary custodian is a market intermediary that keeps detailed computer track of its clients' financial assets. Its custody is only intermediary. However, it proposes a whole range of strictly commercial services with much value added. It actually promotes a rather lossmaking activity, because of its high fixed costs, by proposing dataware housing services to his clients.

- All outstanding securities are numbered in the holders' accounts by account managers/custodians who act as notaries testifying to ownership.

- A custodian, whether intermediary or central, is not responsible for the value of securities, the fluctuations of which depend on market activity and the quality of the issuer. As a consequence, the holder fully accepts capital risk.

- An intermediary custodian, which is CSD affiliate, can act as a link between the CSD and a foreign bank, a global custodian or an ICSD. In such a case, it will be termed a local custodian. For want of a direct economically justified link, foreign actors often have to turn to a local custodian, which provides information about local functional and legal practices.

- Central custodians are not issuers; they just keep record of the securities issued in the country where they work.

- A central custodian/depositary is the guarantor of the market's trust in the existence of outstanding securities. It testifies to the authenticity of securities, and ensures their traceability, for want of which trading would not be possible.

Knieps (2004) considers the two functions (authentication and certified ownership) to be two elements of the notary function. This, we believe, is hardly acceptable insofar as both these functions are not performed by the same actor ; moreover, it assumes that the functions of intermediary and final custodians are subject to the same systemic risks, which is not the case.

- Should an intermediary custodian fail, a certain number of people, and even institutions, would feel the pinch, just as they would if fuel deliveries came to a halt. Although the problem might prove preoccupying because of the importance of certain actors, this form of failure and mistrust stays at a local level

- Should a final custodian fail, mistrust would encompass all securities in a given country, which would generate systemic risk. No one would be in a position to say if the securities do exist or not, if their stock tallies with what the final issuers have issued over time, if the corporate events have been insured. A process of general mistrust would thus be triggered, the consequences of which are more reminiscent of those of the BSE epidemic than those of power disruptions in California.

The risk is big enough for this function to be regarded as a key factor in market reliability. "A central depositary is a prerequisite to any basic service provision by an efficient S\&D system" (Karyotis, 2005). As a matter of fact, most countries do have a central custodian. 
Over time, the function organising the circulation of securities has taken precedence over the notary function (12), in relation to the increasing number of transactions and the absence of recent scandals involving the circulation of forged securities.

\section{Changes resulting from dematerialisation}

The development of the circulation function : traceability.

Dematerialisation has provided a custodian with new functions. Not only does it play a keeper's role, but he also ensures authentication and traceability. In this respect, just as a central bank, as a currency authenticator, manages the circulation of bank money through its big-amount payment systems, so a custodian, as a security authenticator, manages the circulation of dematerialised securities through S\&D systems (13). In a completely dematerialised environment, as in France, a custodian/stock manager has to "organise" stock inflows and outflows vis-à-vis intermediary custodians (possibly with the "CCPs" (14)). Since the introduction of the euro, the hallmarks of payment and S\&D systems (15) have been closely linked, due to Lamfallussy rules (gross settlements for Target-linked, RTGS-affiliate S\&D systems).

The development of collateralisation services; liquidity inflow into the loan-borrowing market

The centralisation of post-trade operations has gained particular significance as the actors in the same financial centre may be members of different clearing houses (this is not true of Euronext). Now, an actor's default in a given market may propagate to other markets. In this case, a central depositary can curb the chain reaction by proposing the collateralisation of the traded securities (16). It thus enhances market safety and liquidity, trading and settlement systems efficiency by developing security loans and borrowings as well as collateralisation. In money markets, the bank-money circulation of securities via a central depositary is essential to the flexibility of the system and to the collateralisation of loans imposed by a central bank to intervene (17). Its role could be likened to that of a securities lender of last resort; however (and this is to be stressed), it does not issue the securities itself, but can only make them available at a bank's request.

The appearance of new actors due to the development of trade at a world level

\section{ICSDs}

1 - They perform the function of central depositaries of international securities.

Historically, ICSDs perform the same functions as domestic depositaries, but they are mainly specialised in custody, clearing and the S\&D of international securities.

It was Morgan Guaranty Trust of New York that set up Euroclear in Brussels in 1968. 120 financial intermediaries gradually acquired shares of its capital (18). CEDEL (19) was created in 1970 by Morgan's main competitors to counterbalance Euroclear's monopoly. The development of euromarkets implied the creation of centres capable of clearing, S\&D, and the custody of "Xenosecurities" (in particular eurobonds), which are, by definition, deprived of national identity. In this perspective, CEDEL/Clearstream (20) and Euroclear positioned 
themselves successfully in the same market niche as CSDs. The acronym ICSD is thus perfectly justified as they are final central depositories of securities deprived of national identity.

2 - They also propose related services.

ICSDs, however, do not limit themselves to this role. They intervene in transactions involving national securities when one of the contracting parties is non-resident. It means more complexity since ICSDs, in some countries, are not allowed to have direct relationships with CSDs (21). They do not necessarily have an account with each CSD, even though it is possible. This is why they have relationships with local correspondents (banks, local custodians), which have direct access to a CSD and its S\&D systems. In Europe, securities are held in these banks on Euroclear, Clearstream or SEGA Intersettle's behalf. Relationships between CSDs and ICSDs just intersect so long as the domestic and the national make one, but there emerge joint cost-cutting schemes, benefiting support functions, as soon as CSDs develop mutual links, or ICSDs "buy" local CSDs. Moreover, with the changing size of the domestic, the share of international trading keeps increasing. This is the way tasks must be performed by ICSDs:

- in the case of a domestic security processed by domestic counterparties, and denominated in the local currency, the relationship is settled by a CSD; this kind of transaction will obviously grow scarce;

- regarding a domestic security, the relationship is settled by an ICSD if either or both parties are not domestic;

- if the security has no national identity, the relationship is closed out by an ICSD, whatever the nationality of the investors.

If we consider circulation as such, the change from national to European leads logically to the replacement of CSDs with ICSDs. This statement must be qualified if we take the authentication of securities into account, as will be seen below.

ICSDs also propose a whole range of services with value added. In this case, they perform a function of intermediary, and not final, custodians, which partly overlaps the function of global custodians.

Intermediary custody has become a strategic means in the development of certain financial institutions at a world level. It is known as global custody when banks process the securities of many countries. A global custodian deals administratively with the securities under different national regulations. Most of the time, they sub-contract with local subcustodians (22). This results from the globalisation of investment, and the massive presence of AngloSaxon investors in continental Europe, who want to diversify their portfolios and multiply cross-border operations. Custodians adopt a commercial approach to investors. They are service providers whose function encompasses other activities than strictly administrative and technical ones. Among these activities, let us mention:

- information about portfolios (evaluation, reporting);

- technical data about markets;

- tax procedures;

- management of loans/borrowings against securities;

- management of demand deposit accounts backed by securities accounts;

- risk analysis;

- proxy voting. 
At a world level, the market for asset custody is highly consolidated and dominated by American banks (23), which pioneered custody as a profession worthy of the name. The charts here above show their respective market shares.

This activity, which heavily relies on capital investment in computer systems, aims to attract new institutional investors, credit or investment firms wishing to sub-contract their own custody business. Custodians constantly try to make economies of scale through mass processing, while keeping in a position to meet specific requests from their actual or potential clients.

All in all, when what is national and what is international can be clearly identified, the relationships between these different actors can be shown as follows.

In fact, this case is rather similar to that of correspondent bank accounts in an international payments context. What local custodians mean to securities is what correspondent banks mean to money. They have access to the S\&D systems of CSDs ensuring the delivery and final custody of securities. They are the organic link banks have to create in the absence of a link with a foreign SSS (24). Due to the shortcomings of a non-system, specific functions are developed to be used as makeshifts. If we push the comparison with the payment systems a little further, the shift from the national to the domestic (in the European sense of the word) should obviously entail an institutional simplification for the operations performed within the domestic. This is why it is so important to give a proper definition of the domestic.

\section{THE MAKING OF EUROPE: \\ THE SEPARATION BETWEEN THE NATIONAL AND THE DOMESTIC}

18 The making of a "domestic Europe of securities" raises many questions to the S\&D custody business. On the face of it, a mere shift from a national domestic area to the European domestic one allows to envisage the existence of a single "European domestic CSD" all European intermediary custodians could have access to. It would administer a pan-European S\&D system, and act as final custodian of "European" securities. Such an entity would raise thorny questions concerning the existence of national CSDs, the raison d'etre of global custodians, which would lose some of their prerogatives, the positioning of ICSDs, and the status of a single domestic CSD.

What we mean by domestic area for securities has to be developed, regardless of institutional issues. Should this area be shaped up on the pattern of a homogenous regulatory area, or after the euro community area, or should it have the form of a "technological" unit that would fully integrate the securities processing line, following a deep remodelling of current legal mergers into technological mergers between the different market infrastructures? These three approaches could well coexist. They show how complex the current organisation is, with its converging regulations, its integration of markets and systems within a sophisticated, multi-levelled system (EEE (25), UE (26), MCE2, Eurosystème), its market consolidation of infrastructures (especially S\&D) for activities the scope of which is increasingly global.

Analysing these issues implies a helpful study of the construction of monetary Europe to point out the similarities and differences, and highlight the specificities of the construction. 
Political will, in the field of monetary construction proved strong. The shift from a monetary community (the euro account community) to a community of payments worthy of the name involved significant means and efforts. Giving up monetary sovereignty and setting up a federal body (the ECB) do evidence this will. Yet, it did not prove strong enough to lead immediately to a fully integrated system. It brought about an ECB-monitored harmonisation of the national systems (via Target) for big amount payments. Small payments, for their part, were initially subject to the law of the market. Spontaneous adjustment did not occur, and payment infrastructures for small amounts remained scattered after the adoption of the euro (several clearing houses the balances of which were closed through the systems of the different national central banks). This situation called for the intervention of regulatory authorities.

\section{The role of the European commission in regulatory matters}

Regulation indeed was what gave a strong push to the Europe of the systems of payments. A decisive incentive was provided to banks by the adoption of the European regulation which regards cross-border transfers within the EU as "domestic" transfers. Banks had to reconsider the processing procedures of transactions. The SEPA scheme, EPC's achievements (28), panEuropean debit are integral parts of this approach aimed at strengthening payment infrastructures, and even creating pan-European structures (PEACH) to keep costs under control and streamline the processing of operations. If banks promptly reacted to the implementation of the SEPA scheme, it is because a European regulation expressed its refusal to pass the construction cost of the Europe of payments on to the consumer. It would have been politically infelicitous, in an enlarged euro-payment community, to overcharge small amount cross-border payments, even though it was technically feasible due to the presence of fragmented payment systems in a single monetary area.

\section{How a political will has imposed itself on financial institutions to build up a gemine system}

Before the introduction of the euro, banks used correspondent accounts for payments inside the European Union. Building up monetary Europe implied using the concept of a monetary union relying on a new unit of account. The ECB set up new infrastructures to transfer big amounts, thus helping the union to materialise into a large payment community. Target helped the shift from a non-system (no specific infrastructures) to a genuine system. It put an end to correspondent banking.

As for currency circulation at a world level, correspondent accounts have permitted international payments between different monetary areas. The birth of CLS in 2002 accelerated the decline of correspondent banking to the benefit of this new multi-currency clearing infrastructure.

Two important remarks can be made.

- Correspondent banking as a non-system is eclipsed by specific infrastructures. As soon as effective infrastructures are built (see CLS), correspondent accounts look historically dated (in particular "cash" correspondent accounts).

- In Europe, the ECB as the legitimate authenticator of the euro stock has been placed, thanks to Target, at the core of this currency's circulation. 
There has been much less determination in making the Europe of securities. Currently, the difficulty stems from the multiplicity of the breakthroughs (converging regulations, mergers between Bourses, rapprochements between CCPs and CSDs) and their insufficient degree of attainment (regulations that lack unity, legal mergers without systemic integration etc. (29)).

The absence of a strong political will can be accounted for by other reasons than the fallacious impression that it is a strictly technical, and therefore boring, subject matter (30). Among these reasons:

- no S\&D systemic risk has emerged, making the implementation of a real panEuropean infrastructure even more urgent, as was the case with CLS (Herstatt risk) in foreign exchange markets (31);

- the construction of the Europe of securities raised the question of who, at a European level, could have sufficient legitimacy to perform the authentication function, given the disappearance of the national dimension, and the non-existence, at the moment, of strictly European mutual institutions. The manager of a "securities Target" should be a sort of ECBS (European Central Banks System) for securities. This raises many questions. Who could manage the core of the system? Who could organise the circulation of securities in the absence of a legitimate authenticator?

For want of a satisfactory outcome, stopgap solutions have been adopted. CCBM has been implemented as an interim system facilitating the use of another country's collateral securities in the case of repo operations with the ECB in order to have access to central bank currency. With the development of direct links between European CSDs aimed at facilitating the crossborder circulation of the collateral, correspondent accounts should have been given up. The under-utilisation of these links explains the longevity of the CCBM, counter to all expectations, and its being still the most used system, whereas it is the very illustration of a non-system.

\section{The painful birth of regulation}

A stalemated political Europe has caused the determination of public authorities to lose its edge. The idea of a European code of securities has long been considered premature, and the construction of the Europe of securities falls outside the scope of most citizens' concerns. As in the case of small amount payments, one may wonder whether a regulation could be envisaged to speed up its implementation.

The Directive on markets and financial instruments (MIF Directive) adopted in the spring of 2004 chiefly bears on market functions through competition between traditional Bourses and electronic trading facilities (32), and through the internalisation of orders. By contrast, it deals with post-market functions in a succinct way.

The core of the current debate within Europe is the utility of a directive that would provide post-market functions, notably S\&D, with an organising framework. The supporters of regulation (33) advocate the adoption of a directive aimed at separating the infrastructures from their users. The opponents (34) uphold the idea that it is the market itself that has to organise the future of the settlement and clearing business through competition between the actors concerned. At the moment, no decision has been made as to the relevance of the regulation. The Commission has asked for an impact study, the conclusions of which should be known in early 2006. The Kauppi report (35) of July 2005 only reasserted the principle of the harmonisation of regulations at a European level (information on prices, free access, system safety). 
The Commission will have to answer the question about its obligation, or absence of obligation, to shape up S\&D regulation in imitation of cross-border payments regulation. Supposing that it adopts such a rules, it will then be the job of operators to speed up the harmonisation process and the consolidation of the systems. In this perspective, they will be unable to pass the costs of cross-border processing on to investors in an area (the $25 \mathrm{EU}$ countries) regarded as domestic (despite the diversity of the systems). This assumption implies that the Commission will also have to make a clear decision respecting the entity that will authenticate and manage the circulation of securities. If this proposal is repelled, the market will be the sole organising power, and will rely on industrial mergers. This is the way the Europe of securities is currently building itself up, in the absence of strong-willed regulation.

\section{The authentication problem is not resolved by partial regulatory frameworks based on industrial mergers.}

Cross-border operations involve a human factor which makes them less reliable (data-keying problems/operational risk), longer, and more expensive. For the time being, Straight Through Processing is unachievable internationally. As a consequence, it is extremely important, from an industrial standpoint, to standardise practices technically. This is what a certain number of firms that have merged have tried to do. All cross-border mergers, it must be noticed, have hinged on a single depositary having relationships with national depositaries. Clearly enough, the approach here is strictly industrial as in the case of mergers between traditional firms.

On the face of it, there is no reason why the industrial and the monetary (and therefore the political) should converge. From this perspective, there is a contradiction between the shaping of the European financial landscape into a homogenous integrated area and the restructuring of market conglomerates (macro-CCP, macro-CSD).

Infrastructures are taken into account and, from this standpoint, an integrated operation, in the technical sense of the word, and without reference to the European construction or the euro zone, becomes "domestic". Certain integrated areas go beyond the limits of the monetary area, whereas fragmented areas still exist within the same monetary community.

Let us take three examples:

- all Euronext securities markets belong in the euro zone.

By contrast, such is not the case of the derivatives markets (Euronext-Liffe) or the postmarket business, with the LCH.Clearnet and Crest/Euroclear mergers. They are examples of technically integrated domestic areas that do not belong in the same monetary area;

- similarly, the existence of LCH.Cleaner and the integration of CREST into Euroclear could be legitimately termed "domestic" operations, whereas the separate development of the securities business in France and Germany would rather be termed a cross-border operation

- the same phenomenon can be observed in North European markets: in 2003, OM Group and HEX (Finland) merged Bourses that belonged in different monetary areas.

$\mathrm{OMX}=\mathrm{OM}+\mathrm{HEX}+$ Vilnius + Tallin.

They are mergers between euro zone countries (Finland), inside and outside MCE.

However, it must be remembered, following Tapking (2005), the mergers so far have not resulted in a complete technological integration, even if the determination to achieve it is potent. For the time being, they are just legal mergers.

Technological integration will indeed simplify the circulation of securities and reduce transaction costs. 
However, the problem remains whole if the authentication function is taken as a standpoint. In this case, the legitimacy of the custodian (ICSD) as an authenticator is a reality only for the group members (Euronext for instance) with which it has entered into a cooperation contract. Vis-à-vis other actors, this legitimacy does not exist or can be questioned (as was the case for Clearstream). The custodian must then derive its legitimacy from one or several institutions. Obviously, such a situation cannot last. Now, the CESR makes no pretence of becoming a European regulatory authority soon.

In this article, we have chosen to leave the circulatory aspects of S\&D partly aside in order to concentrate on the authentication and traceability functions of central depositaries, with a view to assessing the changes that have characterised these institutions. This has required a comparison with payment systems.

This approach has enabled us to point out that the similarities between securities circulation and currency circulation are very significant, and that the integration of payment systems, which is more advanced than that of S\&D systems, might provide useful information about the changes to be desired in different institutions. Laying the emphasis on the authentication function, which is closely linked with systemic risk, has also enabled us to show that strictly "circulatory and industrial" approaches sideline questions we think essential to the construction of a European integrated securities market.

\section{NOTES}

1. The institutions ensuring custody will be termed as depositaries or custodians. "Depositary" must be taken in its generic sense, and not in the French sense of "dépositaire d'OPCVM".

2. This transaction is achieved by markets intermediaries with their secondary systems. They dish out the cash transfers and the securities received from the financial centre's intermediaries among the final customers - buyers or sellers.

3. A distinction must be made between the national, which relates to a country as such, and the domestic, which relates to a given area.

4. Euroclear France has two of them: RGV and Relit+.

5. See AFTI survey, November 2002.

6. See the Livre bleu, April 2004.

7. Giovannini report 2001 and 2003.

8. Circulation circuits are closely interwoven and present quasi similar hallmarks (gross or net systems). "Custody" time periods are nearly identical, due to the growing turnover of portfolios and the relative stability of near-money. The liquidity of securities has considerably increased, particularly through the presence of marketmakers, and the shortening of S\&D time. Transaction costs for securities have considerably decreased, and tend to increase for currency. Capital risk for securities can be avoided thanks to the use of derivatives.

9. Think of Pandora's box and all the evils that followed its opening.

10. The risk suffered by depositors has nevertheless been studied by Diamond and Dybvig through bank-panic models.

11. See Chanel-Reynaud, Chabert «L'infrastructure européenne ; quels schémas de développement pour la future Europe des titres? », La Revue Banque éditeur, third chapter.

12. This is a very telling example of "blindness to impending disaster", even if the suspicion Clearstream had to cope with for some time, or the markets' sharp reactions 
to the manipulation of information about Enron securities show that the scenario is not purely theoretical.

13. AMF's regulation: Central depositaries ensure the circulation of the financial instruments among their members, check that there is strict equality between the total number of the financial instruments issued and the number of the instruments in their members' accounts, see to it that the working rules are complied with by the members, and inform the AMF about whatever breach of rules by one of the members.

14. Central counterparties, if any.

15. The French "règlement-livraison", insofar as it refers to the simultaneity of cash payment and securities delivery.

16. Humphrey D.B., Sato S., "Transforming payment systems" World Bank Discussion Papers, 1995.

17. To bear this out, Perold (1998) indicates that securities deposited with a central final custodian, together with the creation of the Central Certificate Service, which succeeded the DTC, was a key factor in ending the US back-offices crisis in the late 1960s. More than that, Perold holds that the absence of deposited securities sparked off Bombay's stock market crisis in 1992. As a matter of fact, the crisis was caused by some operators' utilization of significant time lags in the delivery procedure, due to the need to deliver the securities physically.

18. Catherine Karyotis, 2005, "Mondialisation des marchés et circulation des titres », Revue Banque édition, p. 152.

19. Securities delivery centre.

20. The merger between the German DBC and Cedel resulted in the birth of Clearstream.

21. Banks have long rejected this possibility as they often had stockholdings with the local CSD, and believed that trading in domestic securities was no ICSD's job.

22. They are local and even regional custodians (in the euro zone, for instance) when they only manage the securities of an area.

23. The major custodians in the world are State Street $(\$ 9100 \mathrm{bn})$, Bank of NY (\$8906bn), JP Morgan (\$8014bn), Citigroup (\$6640bn), BNP Paribas (\$2958bn), Mellon Group (\$2946bn),UBS, Northern Trust, HSBC IFS and Sté Générale. Source: La Tribune 23 November 2004.

24. For Security Settlement System.

25. European Economic Area.

26. European Union.

27. Single European Payment Area.

28. European Payment Council.

29. See Tapkings's article(2005).

30. This viewpoint is debatable and needs being debated, the more so since the adoption of the green book on the policy of financial services (2005-2010). The Europe of securities is made "tangible" by the ambition of a Europe of Savings capable of meeting the requirements generated by the new constraints relating to the funding of retirement pensions and the ageing of the population.

31. It must be remembered that the implementation of CLS took place almost 30 years after the materialisation of Herstatt risk.

32. Multi Trade Facilities.

33. It is the stance taken by the Fédération bancaire française.

34. See, for instance, the Villier report (2005) "Our focus should be on bringing down the cost of cross border clearing and settlement, which is usually higher than for domestic transactions. A directive is not the best way to do this." 
35. See the European Commission's website www.europa.int (financial markets' infrastructure). 